\title{
Analisis Kestabilan Model Matematika pada Pertumbuhan Kanker dengan Pengobatan Menggunakan Virus Oncolytic
}

\author{
Nur Faizah $^{1}$, Budi Cahyono ${ }^{2}$, Aini Fitriyah ${ }^{3}$ \\ 1,2,3 Universitas Islam Negeri Walisongo \\ *faizah_1508046021@student.walisongo.ac.id
}

\begin{abstract}
ABSTRAK
Pada artikel ini dibahas analisis kestabilan model matematika pada pertumbuhan kanker yang pengobatannya menggunakan Virus Oncolytic. Model matematika pada penelitian ini diasumsikan bahwa sel kanker yang terdapat pada tubuh penderita terdiri dari sel kanker yang tidak terinfeksi Virus Oncolytic $(\dot{x})$ dan sel kanker yang terinfeksi Virus Onvolytic $(\dot{y})$. Oleh karena itu, sel kanker yang dimodelkan merupakan sistem persamaan differensial nonlinear orde satu dengan dua variabel. Adapun analisis yang dilakukan pada penelitian ini dilakukan secara analitik dan numerik. Analisis secara analitik meliputi langkah-langkah seperti penentuan titik kesetimbangan, analisis kestabilan lokal dan analisis kestabilan global sedangkan analisis secara numerik dilakukan dengan bantuan aplikasi MATLAB. Dari hasil penelitian diperoleh empat titik kesetimbangan dengan kondisi kestabilan setiap titik-titiknya bersyarat. Artinya kestabilan titik kesetimbangan tersebut berlaku jika syarat tersebut dipenuhi. Salah satu kestabilan yang diperoleh adalah Titik Ekuilibrium $T_{1}$ stabil lokal jika dan hanya jika $d>r$ dan $\alpha>s$. Setelah dilakukan analisis secara analitik dilanjutkan dengan mencari simulasi numerik untuk mengilustrasikan dan menguji hasil analitiknya. Adapun hasil numerik yang diperoleh adalah grafik-grafik menunjukkan bahwa solusi dari sitem tersebut stabil. Hal itu menunjukkan bahwasanya pengobatan kanker dengan menggunakan Virus Oncolytic memperoleh hasil yang baik.
\end{abstract}

Kata kunci: kanker, virus oncolytic. titik kesetimbangan, kestabilan lokal, kestabilan global.

\begin{abstract}
This article discusses about analysis of the stability of mathematical models on growth of cancers using treatment Oncolytic Virus. The mathematical model in this article assumes that cancer cells in the body consist of cancer cells that are not infected with the Oncolytic Virus $(\dot{x})$ and cancer cells infected with the Onvolytic Virus $(\dot{y})$. Therefore, the cancer cell modeled is a first order nonlinear differential equation system with two variables. The analysis conducted in this article was carried out analytically and numerically. Analytical analysis includes steps such as determining the equilibrium point, local stability analysis and global stability analysis and numerical analysis is carried out with the help of the MATLAB application. The results of this article obtained four equilibrium points with the stability of each conditional points. This means that the stability of the equilibrium point is valid if the conditions are met. One of the stability obtained is Equilibrium Point $T_{1}$ locally stable if and only if $d>r$ and $\alpha>s$. After an analytical analysis has been carried out by looking for numerical simulations to illustrate and test the analytic results. The numerical results obtained are graphs showing that the solution of the system is stable. This shows that cancer treatment using the Oncolytic Virus is getting good results.
\end{abstract}

Keywords: cancer, oncolytic virus, equilibrium point, local stability, global stability. 


\section{PENDAHULUAN}

Kanker merupakan sel-sel abnormal dalam tubuh manusia yang berkembang secara pesat atau tak terkendalikan (Hejmadi, (2010), (Macdonald, dkk., (2005)). Dalam keadaan yang normal sel akan membelah diri jika ada pergantian sel-sel yang sudah mati dan rusak. Sebaliknya sel kanker akan terus membelah diri meski tubuh tidak memerlukannya hingga pada akhirnya akan terjadi penumpukan sel baru yang disebut tumor ganas. Penumpukan sel tersebut bisa menyebabkan kerusakan jaringan normal sehingga bisa mengganggu organ yang ditempatinya (Kurniasari, 2017). Penyakit kanker sampai saat ini masih mejadi problem dunia. Menurut laporan terbaru yang dirilis oleh IARC (Internasional Agency for Reseach on Cancer) tahun 2018 terdapat 18.1 juta kasus kanker baru. Kasus kanker baru yang terdapat di benua asia mencapai hampir setengah dari kasus kanker yang ada di dunia (Kementrian Kesehatan RI, 2015). Sampai saat ini beberapa pengobatan telah banyak dilakukan untuk mengatasi masalah kanker. Usaha-usaha tersebut adalah kemoterapi, pengankatan tumor dan viroterapi. Pengobatan menggunakan kemoterapi dengan dosis yang berlebihan atau tidak tepat, dapat merusak jaringan dan sel normal yang lain dalam tubuh, yaitu sel effektor-immun dan sel sirkulasi limposit atau sel darah putih (Jesse, dkk., 2003). Sedangkan kasus pembedahan menyebabkan diangkatnya seluruh organ (misalnya rahim atau payudara) sehingga organ kehilangan fungsinya (Kurniasari, 2017).

Perkembangan ilmu pengetahuan mokuler dan rekayasa genetika menemukan metode pengobatan kanker yang efektif dan spesifik. Pengobatan tersebut adalah Virotherapi yaitu pengobatan yang memanfaatkan sifat virus untuk menghancurkan kanker (Kurniasari, 2017). Virus yang digunakan dalam pengobatan kanker disebut Virus Oncolytic. Oncolytic berasal dari kata Onco yang berarti tumor dan Lytic yang berarti lisis Virus Oncolytic merupakan virus hasil rekayasa genetika melalui penggabungan DNA atau RNA virus dengan DNA dari gen lain (Kuruppu, 2005).

Pengobatan kanker dengan menggunakan Virus Oncolytic sampai sekarang terus berkembang dan menjadi perhatian. Pada pertengahan abad ke-20 pengobatan menggunakan Virus Oncolytic sudah dimulai Usaha awal difokuskan pada virus dengan sifat Oncolytic alami, karena belum adanya teknologi yang mampu melakukan rekayasa genetika pada virus. Beberapa penelitian telah dilakukan menggunakan berbagai macam virus, diantanya virus Hepatitis B untuk penyembuhan kanker kelenjar getah bening, virus Egytp 101 untuk penyembuhan berbagai jenis kanker, adenovirus untuk penyembuhan kanker serviks dan lainlain (Pagalay, 2009).

Permasalahan pada pertumbuhan kanker dengan pengobatan menggunakan virus oncolytic sangat kompleks maka perlu dilakukan perhitungan terkait hal tersebut agar pengobatan mencapai hasil yang sesuai harapan. Oleh karena itu, untuk memudahkan melakukan perhitungan maka diterapkan model matematika (Hikmah, 2009). Model matematika pada kasus pertumbuhan kanker dengan pengobatan menggunakan Virus Oncolytic sangat dibutuhkan untuk mengetahui perilaku antara sel kanker dengan virus yang disuntikkan kedalam tubuh (Novellina,dkk, 2016).

Model dinamika pertumbuhan kanker yang pengobatannya menggunakan virus Oncolytic telah diteliti banyak ahli salah satunya oleh Novozhilof (2006) dan Wodarz (2004). Dalam penelitian Wodarz sel kanker tidak dapat dihilangkan melainkan hanya dapat dikurangi ke 
tingkat yang sangat rendah. Pada penelitian ini akan dibahas analisis kestabilan model matematika pada pertumbuhan kanker dengan pengobatan menggunakan Virus Oncolytic yang diambil dari Wodarz (2004).

\section{METODE}

Metode yang digunakan pada penelitian ini adalah mencari solusi sistem persamaan differensial dari model yang terbentuk dengan cara analitik dan numerik. Metode analitik digunakan melalui langkah sebagai berikut: 1) mencari titik kesetimbangan, mencari titik kesetimbangan dilakukan dengan cara membuat sistem persamaan differensial homogen atau sama dengan nol (wiggins, 2003). 2) meyelidiki kestabilan titik kesetimbangan Menyelidiki kestabilan titik kesetimbangan diharuskan mengetahui solusi sistem terlebih dahulu sedangkan mencari solusi dari sistem terlebih sistem non-linear tidak selalu mudah dan sebagian besar alasan diselidikinya titik kesetimbangan adalah karena sulitnya mencari solusi dari sistem itu sendiri. Untuk mengatasi masalah tersebut digunakan linearisasi pada sistem persamaan diferensial tersebut (Luenberger, 1979). Mencari hasil dari pelinearan sistem persamaan diferensial yang tak linear dengan cara mensubstitusikan nilai-nilai titik kesetimbangan ke dalam Matriks Jacobian. Matriks Jacobian adalah matriks semua turunan parsial orde pertama. Setelah mendapatkan Matriks Jacobian yang sudah disubstitusikan titik-titik kesetimbangan langkah selanjutnya adalah mencari nilai-nilai eigen. Nilai-nilai eigen dicari dengan mencari skalar-skalar yang memenuhi persamaan karakteristik dari matriks Jacobian yang telah disubstitusikan titik kesetimbangan. Setelah mendapatkan hasil analisis kestabilan lokal maka di cari analisis ketsabilan global dengan bantuan fungsi Lyapunaov.

\section{HASIL DAN PEMBAHASAN}

\subsection{Model Matematika}

Model pertumbuhan kanker dengan pengobatan menggunakan virus Oncolytic terdiri dari dua persamaan yaitu kanker yang tidak terinfeksi Virus Oncolytic $(\dot{x})$ dan sel kanker yang terinfeksi Virus Oncolytic $(\dot{y})$. Berdasarkan asumsi tersebut model yang dikonstruksi oleh Wodarz (2016) adalah sebagai berikut.

$$
\begin{aligned}
& \dot{x}=r x\left(1-\frac{x+y}{k}\right)-d x-\beta x y \\
& \dot{y}=\beta x y+s y\left[1-\frac{x+y}{k}\right]-\alpha y
\end{aligned}
$$

\section{Keterangan:}

$\dot{x} \quad$ : populasi sel tumor tidak terinfeksi pada saat $0 \geq \mathrm{t}, \mathrm{y}(\mathrm{t})$

$\dot{y} \quad$ : populasi sel tumor belum terinfeksi virus pada saat $0 \geq \mathrm{t}, \mathrm{x}(\mathrm{t})$

$\mathrm{r} \quad$ : konstanta laju pertumbuhan sel tumor belum terinfeksi

$\beta \quad$ : konstanta laju infeksi sel tumor oleh virus bebas

d : konstanta laju kematian tumor secara alami. 
$\alpha \quad$ : konstanta laju kematian sel tumor yang terinfeksi

$\mathrm{s} \quad$ : laju pertumbuhan tumor yang terinveksi virus

$\mathrm{k}$ : ukuran maksimal tumor / carrying capacity.

Adapun model pada persamaan (1) memiliki sekma sebagai berikut.

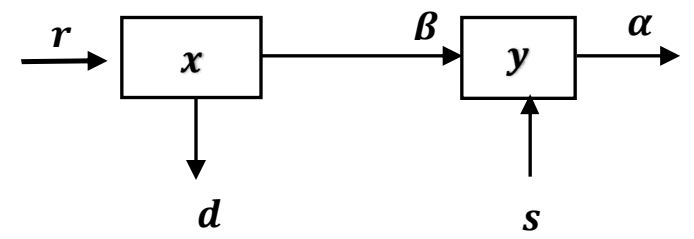

\subsection{Titik Ekuilibrium}

Dengan menjadikan sistem persamaan (1) homogeny atau sama dengan nol diperoleh titik kesetimbangan sebagai berikut.

$$
\begin{aligned}
& \boldsymbol{T}_{\mathbf{1}}=(0,0) \\
& \boldsymbol{T}_{\mathbf{2}}=\left(\frac{k(r-d)}{r}, 0\right) \\
& \boldsymbol{T}_{\mathbf{3}}=\left(0, \frac{k(s-\alpha)}{s}\right) \\
& \boldsymbol{T}_{\mathbf{4}}=\left(\frac{\beta k(\alpha-s)+\alpha r-d s}{\beta(\beta k+r-s)}, \frac{\beta k(r-d)+s d-\alpha r}{\beta(\beta k+r-s)}\right)
\end{aligned}
$$

Berdasarkan nilai titik-titik kesetimbangan $T_{1}, T_{2}, T_{3}$, dan $T_{4}$. Terdapat beberapa kondisi yang harus diikuti oleh setiap titik kesetimbangan. Adapun kondisi-kondisi tersebut adalah sebagai berikut.

a) Titik kesetimbangan $T_{2}$ dan $T_{3}$ ada jika dan hanya jika $r>d$ dan $s>\alpha$

b) Titik kesetimbangan $T_{4}$ ada jika hanya jika mengikuti salah satu kondisi sebagai berikut.

i. $\quad \beta k<s<\beta k+r$ dan maksimum $\left\{\frac{\alpha-\beta k}{s-\beta k} r, 0\right\}<d<\beta k\left(\frac{\alpha}{s}-1\right)+\frac{\alpha}{s} r$

ii. $s<\beta k$ dan $0<d<\operatorname{minimum}\left\{\frac{\alpha-\beta k}{s-\beta k} r, \beta k\left(\frac{\alpha}{s}-1\right)+\frac{\alpha}{s} r\right\}$

iii. $s>\beta k+r$ dan maksimum $\left\{\beta k\left(\frac{\alpha}{s}-1\right)+\frac{\alpha}{s} r, 0\right\}<d<\frac{\alpha-\beta k}{s-\beta k} r$

\subsection{Analisis Kestabilan Lokal}

Untuk menyelidiki kestabilan lokal titik kesetimbangan model, dilakukan dengan cara mensubstitusikan titik-titik kesetimbangan kedalam sistem yang telah dilinearkan. Melinearkan sistem persamaan tersebut menggunakan matriks jacobian $(J)$ yang berordo $2 \times 2$ sesuai dengan sistem persamaan (1).

$$
J=\left(\begin{array}{ll}
J_{11} & J_{12} \\
J_{21} & J_{22}
\end{array}\right)
$$

Adapun matriks Jacobian sistem (1) adalah sebagai berikut.

$$
\begin{array}{ll}
J_{11}=r\left(1-\frac{x+y}{k}\right)-\frac{r}{k} x-\beta y-d & J_{21}=\beta y-\frac{s}{k} y \\
J_{12}=-\beta x-\frac{r}{k} x & J_{22}=s\left[1-\frac{x+y}{k}\right]-\frac{s}{k} y+\beta x-\alpha
\end{array}
$$




\subsubsection{Analisis Kestabilan Lokal Titik Kesetimbangan $T_{1}$}

Dari hasil substitusi $T_{1}(0,0)$ ke persamaan (2) diperoleh matriks Jacobian sebagai berikut.

$$
J=\left(\begin{array}{cc}
r-d & 0 \\
0 & s-\alpha
\end{array}\right)
$$

Dengan membentuk persamaan karakteristik dari Matriks Jacobian diatas $\operatorname{det}(\lambda I-J)=0$ diperoleh nilai eigen yaitu $\lambda_{1}=r-d$ dan $\lambda_{2}=s-\alpha$. Suatu titik kesetimbangan dikatakan stabil asimtotik lokal, apabila semua bagian real dari nilai eigen dari matriks $J f(\bar{x})$ bernilai negatif. Oleh karena itu, agar titik Kesetimbangan $T_{1}$ satbil maka nilai $d>r$ dan $\alpha>s$. Akibat dari kestabilan titik kesetimbangan $T_{1}$ adalah $T_{2}$ dan $T_{3}$ tidak ada. Karena bagian $x$ dari titik kesetimbangan $T_{2}$ yaitu $\frac{k(r-d)}{r}$ akan bernilai negatif jika $d>r$ dan bagian $x$ dari titik kesetimbangan $T_{3}$ yaitu $\frac{k(s-\alpha)}{s}$ akan bernilai negatif jika $\alpha>s$.

Titik kesetimbangan $\boldsymbol{T}_{\mathbf{1}}$ menggambarkan bahwasanya sel kanker yang terinfeksi dan yang tak tidak terinfeksi virus hancur sehingga tidak lagi terdapat dalam tubuh. Dalam analisis kestabilan titik kesetimbangan $\boldsymbol{T}_{\mathbf{1}}$ ditunjukkan bahwasanya $\boldsymbol{T}_{\mathbf{1}}$ akan stabil jika $d>r$ dan $\alpha>$ $s$. Hal itu menunjukkan bahwa tidak lagi terdapat sel kanker dalam tubuh baik sel kanker yang terifeksi oleh virus atau tidak yang terinfeksi oleh virus dikarenakan proporsi laju kematian sel kanker yang tidak terinfeksi virus $(d)$ dan yang terinfeksi virus $(\alpha)$ lebih besar dari pada proporsi laju pertumbuhannya ( $r$ dan $s$ ). Dapat disimpulkan bahwasanya terapi pengobatan berhasil karena tidak lagi terdapat sel-sel kanker dalam tubuh.

\subsubsection{Analisis Kestabilan Lokal Titik Kesetimbangan $\boldsymbol{T}_{\mathbf{2}}$.}

Dari hasil substitusi $T_{2}\left(\frac{k(r-d)}{r}, 0\right)$ ke persamaan (2) diperoleh matriks Jacobian sebagai berikut.

$$
J=\left(\begin{array}{cc}
d-r & \frac{(d-r)(\beta k+r)}{r} \\
0 & \frac{d s-\alpha r+\beta k(-d+r)}{r}
\end{array}\right)
$$

Dengan membentuk persamaan karakteristik dari Matriks Jacobian diatas diperoleh nilai eigen $\lambda_{1}=d-r$ dan $\lambda_{2}=\frac{d s-\alpha r+\beta k(-d+r)}{r}$. Dari titik kesetimbangan $T_{2}$ berlaku $r>d$ sehingga mengakibatkan $\lambda_{1}$ jelas negatif. Suatu titik kesetimbangan dikatakan stabil asimtotik lokal, apabila semua bagian real dari nilai eigen dari matriks $J f(\bar{x})$ bernilai negatif, agar $\lambda_{2}<0$ maka $\alpha>\frac{(\beta k(r-d)+d s)}{r}$ Namun, jika $\alpha<\frac{(\beta k(r-d)+d s)}{r}$ maka $\lambda_{2}>0$. Karena $\lambda_{2}>0$ maka $T_{2}$ adalah titik plana (saddle point).

Titik kesetimbangan $\boldsymbol{T}_{\mathbf{2}}$ menggambarkan pemberian virus Oncolytic tidak mempengaruhi pertumbuhan sel tumor sehingga sel kanker dalam tubuh masih ada karena tidak terdapat penghancuran kanker yang disebabkan oleh virus Oncolytic setelah penyuntikan virus Oncolytic. Analisis kestabilan $T_{2}$ menunjukkan bahwasanya $T_{2}$ stabil jika $r>d$, yang artinya titik kesetimbangan $T_{2}$ stabil jika proporsi laju pertumbuhan sel kanker yang tidak terinfeksi virus 
lebih besar dari proporsi laju kematiannya. Kestabilan pada titik kesetimbangan ini tidak bermanfaat untuk pengobatan karena masih terdapat sel kanker dalam tubuh.

\subsubsection{Analisis Kestabilan Lokal Titik Kesetimbangan $\boldsymbol{T}_{\mathbf{3}}$}

Dari hasil substitusi $T_{3}\left(0, \frac{k(s-\alpha)}{s}\right)$ ke persamaan (2) diperoleh matriks Jacobian sebagai berikut.

$$
J=\left(\begin{array}{cc}
\frac{\beta k(\alpha-s)+\alpha r-d s}{s} & 0 \\
\frac{(\alpha-s)(s-\beta k)}{s} & \alpha-s
\end{array}\right)
$$

Dengan membentuk persamaan karakteristik dari Matriks Jacobian diatas $\operatorname{det}(\lambda I-J)=0$ diperoleh nilai eigen $\lambda_{1}=\alpha-s$ dan $\lambda_{2}=\frac{\beta k(\alpha-s)+\alpha r-d s}{s}$. Dari titik kesetimbangan $T_{3}$ berlaku $\alpha>s$ sehingga mengakibatkan $\lambda_{1}$ jelas negatif. Suatu titik kesetimbangan dikatakan stabil asimtotik lokal, apabila semua bagian real dari nilai eigen dari matriks $J f(\bar{x})$ bernilai negatif, agar $\lambda_{2}<0$ maka $\alpha<\frac{s(\beta k+d)}{(\beta k+r)}$. Sebaliknya jika $\alpha>\frac{(\beta k(r-d)+d s)}{r}$ maka $\lambda_{2}>0$. Akibat dari $\lambda_{2}>0$ adalah $T_{3}$ merupakan titik plana (saddle point).

Titik kesetimbangan $T_{3}$ menggambarkan bahwasanya dalam tubuh masih terdapat sel kanker yang terinfeksi virus karena saat virus disuntikkan kedalam tubuh, virus mampu menginfeksi sel kanker namun tidak menghancurkan sel kanker. Oleh karena itu, kestabilan pada titik kesetimbangan $T_{3}$ tidak bermanfaat untuk pengobatan sel kanker karena pada analisis kestabilan titik kesetimbangan $T_{3}$ mengatakan bahwa titik kesetimbangan tersebut akan stabil jika $\alpha>s$ yang artinya pada titik kesetimbangan ini menunjukkan laju proporsi pertumbuhan sel kanker yang terinfeksi virus $(\alpha)$ lebih besar dari proporsi laju kematiannya $(s)$.

\subsubsection{Analisis Kestabilan Lokal Titik Kesetimbangan $\boldsymbol{T}_{\mathbf{4}}$}

Dari hasil substitusi $T_{4}=\left(\frac{\beta k(\alpha-s)+\alpha r-d s}{\beta(\beta k+r-s)},\right)$ ke persamaan (2) diperoleh matriks Jacobian sebagai berikut.

$$
\begin{gathered}
J_{11}=\frac{r(s(d+\beta k)-\alpha(\beta k+r))}{\beta k(\beta k+r-s)} \\
J_{12}=\frac{(\beta k+r)(s(d+\beta k)-\alpha(\beta k+r)}{\beta k(\beta k+r-s)} \\
J_{21}=\frac{(s-\beta k)(\beta k(d-r)+\alpha r-d s)}{\beta k(\beta k+r-s)} \\
J_{22}=\frac{s(\beta k(d-r)-d s+\alpha r)}{\beta k(\beta k+r-s)}
\end{gathered}
$$

Dengan membentuk persamaan karakteristik dari Matriks Jacobian $\operatorname{diatas} \operatorname{det}(\lambda I-J)=0$ diperoleh nilai eigen

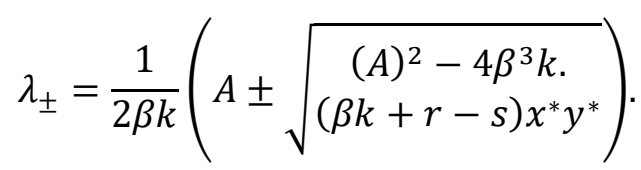

Kestabilan dari titik kesetimbangan $T_{4}$ diperoleh bahwasanya jika $s<r+\beta k$ dan $A>0$ maka $T_{4}$ tidak stabil atau jika $s<r+\beta k$ dan jika $A<0$ maka titik kesetimbangan $T_{4}$ stabil 
asimtotik lokal dan yang terakhir jika $s>r+\beta k$ maka $T_{4}$ adalah titik pelana (saddle point). Titik kesetimbangan $T_{4}$ menunjukkan bahwasanya terdapat sel kanker dalam tubuh, baik yang terinfeksi virus dan yang tidak terinfeksi virus. Namun analisis kestabilan Titik kesetimbangan $T_{4}$ menunjukkan bahwasanya ukuran sel kanker konstan, stabil dan tidak akan tumbuh berjalannya waktu.

\subsection{Analisis Kestabilan Global}

Diberikan fungsi Lypunov $V=x+y$ maka analisis kestabilan global titik kesetimbangan $T_{1}$ adalah sebagai berikut.

$$
\begin{aligned}
& V=x+y \\
& V(t)=x(t)+y(t) \\
& =\frac{\partial V}{\partial x} \frac{\partial x}{\partial t}+\frac{\partial V}{\partial x} \frac{\partial y}{\partial t} \\
& =\frac{k(x(r-d)+y(s-\alpha))-(x+y)(r x+s y)}{k}
\end{aligned}
$$

Hasil analisis kestabilan global yang didapatkan adalah $T_{1}$ akan stabil global jika dan hanya jika $T_{2}, T_{3}$ dan $T_{4}$ tidak ada.

\subsection{Interaksi antara Titik-titik Ekuilibrium}

a. Jika $T_{4}$ adalah titik pelana (Saddle Point) maka $T_{2}$ dan $T_{3}$ ada dan stabil. Serta $T_{1}$ tidak stabil.

b. Jika $T_{4}$ tidak stabil maka $T_{2}$ dan $T_{3}$ tidak ada dan $T_{1}$ stabil.

c. Jika $T_{4}$ stabil maka $T_{2}$ ada dan titi pelana (Saddle Point).

d. Jika $T_{3}$ tidak ada maka $T_{1}$ titik pelana (Saddle Point) dan jika $T_{3}$ ada maka $T_{3}$ adalah titik pelana (Saddle Point) dan $T_{4}$ tidak stabil.

\subsection{Simulasi Numerik}

Diberikan tiga simulasi numerik pada sistem persamaan yakni simulasi pertama, simulasi kedua dan simulasi ketiga menggunakan parameter dengan nilai yang berbeda. Berikut ini adalah nilai-nilai parameter yang akan digunakan dalam simulasi.

Tabel 3.1 Estimasi Parameter

\begin{tabular}{cccc}
\hline Parameter & I & II & III \\
\hline$r$ & 0.2 & 0.2 & 0.1 \\
$d$ & 0.01 & 0.1 & 1 \\
$\beta$ & 0.1 & 0.1 & 5 \\
$s$ & 1 & 1.001 & 2 \\
$\alpha$ & 2 & 1 & 3 \\
$k$ & 70 & 29 & 5 \\
\hline
\end{tabular}


3.6.1. Simulasi I diperoleh grafik di bawah ini.
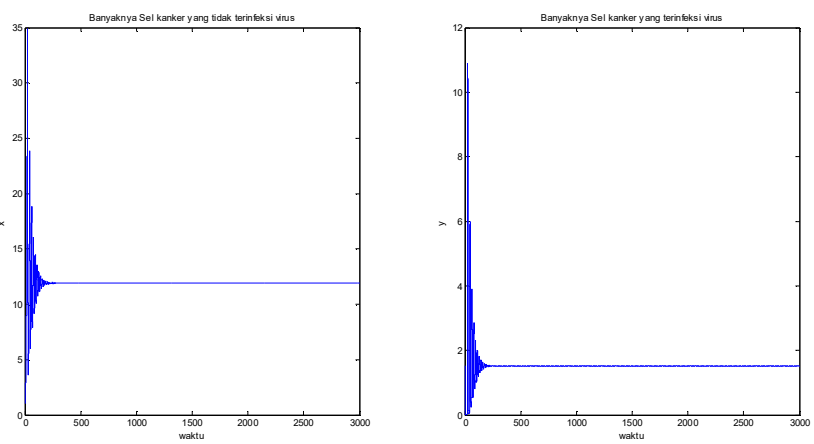

Gambar 1. Kestabilan Titik Ekuilibrium $T_{4}$ pada masing-masing $x(t)$ dan $y(t)$.

Pada Gambar 1 terlihat bahwa laju pertumbuhan sel kanker mengalami penurunan. Selanjutnya laju pertumbuhan mulai naik pada waktu tertentu dan akhirnya populasi sel kanker tidak akan mengalami perubahan atau bisa disebut stabil dalam waktu tertentu. Pada keadaa tersebut, sistem berada dalam kondisi setimbang. Berdasarkan hasil numerik populasi sel kanker yang tida terinfeksi virus mencapai 11.9 dan sel yang terinfeksi virus mencapai 1.5 pada saat $t$ tertentu dan konstan pada titik tersebut.

\subsubsection{Simulasi II diperoleh grafik di bawah ini.}
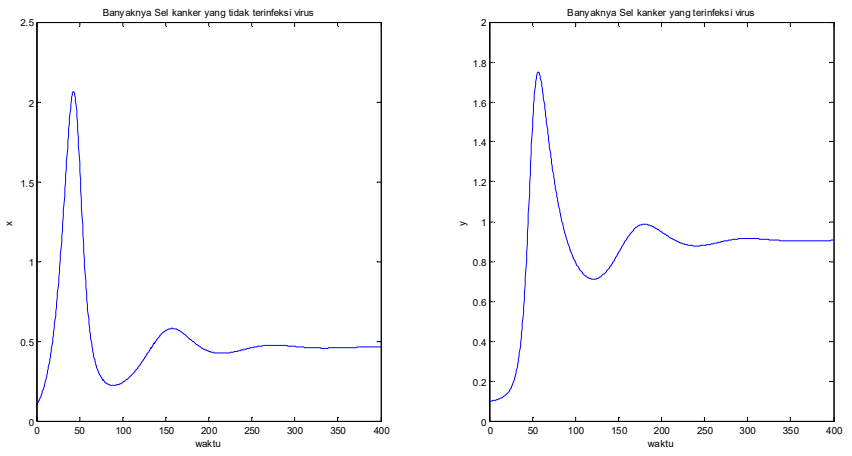

Gambar 2. Titik Ekuilibrium $T_{4}$ Stabil Asimtotik

\subsubsection{Simulasi III diperoleh gambaran sebagai berikut.}

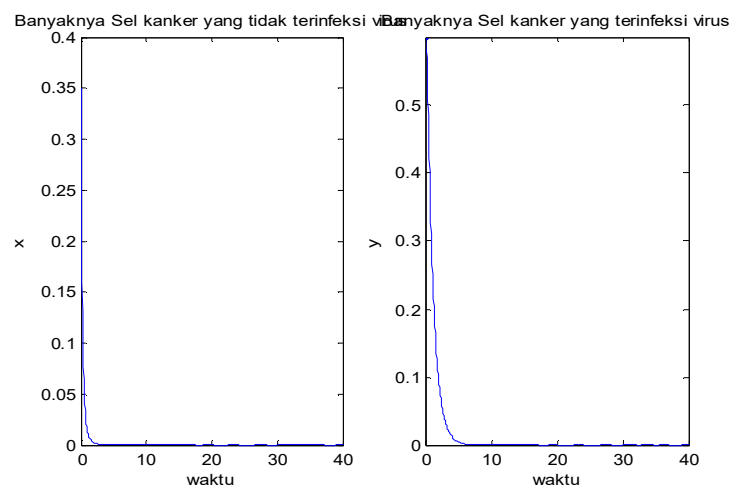

Gambar 3. Titik Ekuilibrium $T_{1}$ Stabil Asimtotik 
Berdasarkan simulasi III dapat diketahui bahwasanya populasi sel tumor baik yang terinfeksi atau yang tidak terinfeksi mengalami penurunan secara terus menerus samapai dimana laju pertumbuhan sel kanker tidak mengalami perubahan atau setimbang. Berdasarkan hasil numerik, populasi sel kanker dalam kesdaan setimbang adalah 0 pada waktu tertentu, artinya sel kanker tidak ada lagi didalam tubuh manusia.

\section{KESIMPULAN DAN SARAN}

\subsection{Simpulan}

Pada penelitian ini, dapat disimpulakan bahwasanya terdapat 4 titik kesetimbangan yang dianalisis pada sistem penelitian ini. Setelah itu, diseledidki kestabilan lokal dan global dari masing-masing titik kesetimbangan. Seperti yang diketahui bahwasanya kestabilan $T_{2}$ tidak berguna karena pada kesetimbangan $T_{2}$ nilai variabel $y$ bernilai nol. Itu artinya tidak terdapat sel kanker yang terinfeksi virus. Pada kestabilan titik kesetimbangan $T_{3}$ diperoleh nilai dari variabel $(x)$ adalah nol, hal tersebut menunjukkan bahwa semua sel tumor terinfeksi akan tetapi virus tidak bisa menghancurkan sel kanker sehingga sel kanker masih mengendap dalam tubuh. Titik kesetimbangan $T_{4}$ adalah titik kesetimbangan yang paling menarik karena kedua titik kesetimbangan $T_{4}$ mengisyaratkan bahwasanya sel-sel kanker terdapat dalam tubuh baik yang terinfeksi maupun yang tidak terinfeksi namun sekalipun kedua jenis sel kanker terdapat dalam tubuh, kestabilan titik kesetimbangan $T_{4}$ mengartikan bahwasanya pertumbuhan sel kanker dapat dikontrol sehingga kanker tidak terus meningkat hingga mencapai batas maksimal

\subsection{Saran}

1. Untuk penelitian selanjutnya bisa dicari analisis kestabilan global untuk $T_{2}, T_{3}$, dan $T_{4}$.

2. Menentukan perlakuan yang berbeda terhadap model, seperti menentukan kontrol optimal terhadap model yang dibahas dengan menambahkan variabel

\section{DAFTAR PUSTAKA}

D. Kuruppu and K. K. Tanabe, "Viral Oncolysis by Herpes Simplex Virus and Other Viruses," Cancer Biology and Therapy, Vol. 4, No. 5, May 2005, pp. 524-31, doi:10.4161/cbt.4.5.1820

D. Wodarz, 2004. Cumputational Approaches to Study Oncolytic Virus Therapy. Insight and Challenges, Gene Ther Mol Biol.

Hejmadi, Momna. 2010. Introduction to Cancer Biology. bookboon.com

Jesse, D. M., Parker, M. T., Fultz, K. E., Ignatenko, N. A., dan Gerner, E. W., 2003. Molecular Biology of Cancer. Volume 5: Chemoteraputic Agents. 6th Ed. New York: John Wiley and Sons

Kemenkes RI, 2015. Hasil Riset Kesehatan Dasar Tahun 2013. Jakarta: Kementerian Kesehatan RI.

Kurniasari, Fuadiyah. dkk. 2017. Buku Ajar Gizi dan Kanker. Malang; Universitas Brawijaya press. 
64 | Nur Faizah, Budi Cahyono, Aini Fitriyah - Analisis Kestabilan Model Matematika pada Pertumbuhan Kanker dengan ....

Luenberger, D. G. (1979). Introduction to Dynamical Sistem Theory, Models, and Applications. Canada: Wiley \& Sons, Inc.

Macdonald, F., Ford, C.H.J, dan Casson, A.G., 2005. Molecular Biology of Cancer. 2nd Ed. London: Garland Science/BIOS Scientific Publishers.

Novellina, Via, dkk. 2016. Analisis Kestailan Model Matematika untuk Penyembuhan Kanker Menggunakan Oncolytic Virotherapy.Jurnal Matematika Universitas Diponegoro. Vol. 19. No. 2. Halaman 72-77.

Pagalay, U..2009. Mathematical Modelling Aplikasi pada Kedokteran, Imunologi, Biologi, Ekonomi dan Perikanan. Malang : UIN-Maliki Press

Rahmah, Hikmah. 2009. Model Dinamika Sel Tumor dengan Terapi Pengobatan Menggunakan Virus Oncolytic. Jurusan Matematika Fakultas Matematika dan Ilmu Pengetahuan Alam. Bogor: Institut Pertanian Bogor.

Wiggins, S. 2003. Introduction to Applied Nonlinear Dynamical Sistem and Chaos, Second Edition. New York: Springer - Verlag. 